\title{
Neon Bull: fashion as metaphor of the contemporary and sensitive experience
}

\section{Suellen Cristina Vieira}

Master's Degree in the Post-Graduate Program in Language Sciences; Specialist in Business Management: Graduated in Fashion Design; Lecturer in the course of Fashion Design - Southern University of Santa Catarina UNISUL/suellen_zimba@hotmail.com

Orcid: 0000-0003-3121-2316 / lattes

\section{Alexandre Linck}

Doctor of Literature (UFSC); Master of Science in Language (UNISUL);

Graduated in Communication Social (UNISUL); Assistant Professor

PPGCL (UNISUL)/linck.alexandre@gmail.com

Orcid: 0000-0001-7500-8312 / lattes

Sent 15/11/2018 /Accept 08/04/2019 


\title{
Neon Bull: fashion as metaphor of the contemporary and sensitive experience
}

\begin{abstract}
Based on the Brazilian feature film Neon Bull (2015), directed by Gabriel Mascaro, the present article aims to understand the dimensions of the identity of the contemporary subject, through the character Iremar. Thus, a discussion is opened between the contemporary, the sensitive and the fashion, under the interpretations of the authors Giorgio Agamben and Emanuele Coccia. The result of the research comes from the concepts and the microanalysis of four scenes examined through the methodology of filmic analysis of the image, according to Jacques Aumont and Michel Marie. It was possible to verify that the narrative of the work in analysis in the referring one to the contemporary world, the sensations and ruptures of stereotypes and paradigms.
\end{abstract}

Keywords: Contemporary; Sensitive; Fashion. 


\title{
Neon Bull: fashion as metaphor of the contemporary and sensitive experience
}

\begin{abstract}
RESUMO
A partir do loga-metragem brasileiro Boi Neon (2015), dirigido por Gabriel Mascaro, o presente artigo tem como objetivo buscar entender as dimensões da identidade do sujeito contemporâneo, por meio do personagem Iremar. Dessa forma, abre-se uma discussão entre o contemporâneo, o sensível e a moda, sob as interpretações dos autores Giorgio Agamben e Emanuele Coccia. O resultado da pesquisa vem do entrecruzamento dos conceitos e da microanálise de quatro cenas examinadas através da metodologia de análise fílmica de imagem, à luz de Jacques Aumont e Michel Marie, a partir do que foi possível constatar que a narrativa da obra em análise nos leva ao mundo contemporâneo, de sensações, e de quebras de estereótipos e paradigmas.
\end{abstract}

Palavras-chave: Contemporâneo; Sensível; Modapalavra. 


\section{INTRODUCTION}

We live in a society in which identities are constructed and shaped by sociocultural discourses, insofar as we are fruits of our environment and related to time and its effervescence. In this sense, contemporaneity brought global, economic, technological and geopolitical transformations on a global scale, with implications for the ways of being and acting in society. From this perspective, the present study opens a debate about the characteristics of the contemporary subject and his worldview.

Thus, in order to understand the dimensions of the identity of the contemporary subject, we propose a discussion between the contemporary, the sensitive and the fashion. In this way, the intertwining of these concepts occurs according to the italian philosophers Giorgio Agamben (2010) and Emanuele Coccia (2010), who use fashion as examples in their texts. If on the one hand, for Agamben, fashion translates the experience of time and contemporaneity; on the other hand, for Coccia, fashion represents the sensitive incarnate, to the point that the fascination for clothing is due to the fact of presenting us from the outside.

For this, the Brazilian film Neon Bull (2015), directed by André Mascaro, is used as an object of study and interlacing of the concepts under analysis. The problematic of this research therefore rests on the reflection about the identity of the protagonist character Iremar during the feature film and how such characteristics of his identity may be related to the formation of the contemporary subjects. According to Agambem, that happens because "one who possesses a unique relation to time itself, which adheres to it and, at the same time, takes it from distances" (AGAMBEN, 2010, p 59).

Based on this premise, the article proposes a filmic analysis of the feature film, taking into account the ways of 
seeing, feeling and expressing the narrative, especially from the point of view of its relations with contemporary concepts, understood as the anachronistic time is inscribed in the archaic and modern never lived (AGAMBEN, 2010); and the sensitive, which, in turn, can be understood as the capacity of the subject to produce images (COCCIA, 2010).

Considering those topics already mentioned it was chosen the interpretive methodology of filmic analysis of image to permeate the present study. Thus, the authors Jacques Aumont and Michel Marie (2004, p.10) use the analysis proposed here, which affirms that "it is almost impossible to correctly analyze a film narrative without intervening considerations related to the its visual aspects". Moreover, according to the aforementioned authors, the analysis has indeed to do with interpretation, insofar as such faculty serves as an inventive and imaginative "engine" for analysis. Under this bias, we opted to analyze four scenes of the feature film, with the selection criterion established due to the relevance and the coherence of the scenes with the concepts approached.

For that, following the methodology presented by Aumont and Marie (2004, p.6), it is understood that there is no universal method for film analysis, since such a methodology can be given through several "instruments" in three types: Descriptive instruments which describe and narrate certain characteristics of the image; Quoted instruments that perform an analytical and meticulous examination keeping closer to the letter of the film; Documentary instruments that collect information from external sources to film. Thus, we call for a descriptive or used instrument, together with an interpretative analysis, in order to understand the concepts in analysis by means of plans, sequences and framing.

Therefore, the research proposed here, beginning with the new looks, seeks to understand postmodern society 
through a contemporary sensorial lens, taking as bias the fashion. In this way, the Boi Neon feature protects these concepts, two of them being an investigation more focused on pointing out new ways of thinking about stereotypes and the elements imposed by culture and society.

\section{THE CONTEMPORARY FROM THE PERSPECTIVE OF GIORGIO AGAMBEN}

Postmodern society has been complex since its inception. That is why constantly debates and discussions arise between thinkers from different areas about what is the time in which we live and how is the subject fruit of this historical and social context. Moreover, the relationships men share in society, including the way they perceive time, allow them to assign specific meanings to various dimensions of their existence.

So, what is time? In Kantian terms "time is no more than the form of the inner sense, that is, of the intuition of ourselves and of our inner state" (Kant, 1985: 73). In this path, for Immanuel Kant the perception of time is spatial, it remains in motion, and always takes place from the point where we ourselves find ourselves.

Thus, under this thought, a question is opened about the concept of contemporaneity. The Italian philosopher Giorgio Agamben in his text, "What is contemporary?" contradicts what the grammatical dictionary says and explains a broader understanding of this concept. This author affirms that, unlike what is commonly thought, he who adheres without friction to his own time, feeling himself in total harmony with himself and his elements, could not be contemporary (AGAMBEN, 2009).

According to Giddens (1991, p.16), "the modern period allowed the emergence of the concept of the free individual, as well as its empirical existence, materialized the validity of 
a new notion of time, in which it is no longer coupled with space, but it appears independently. "That is, this new time makes possible the clear distinction between a "before", a "now" and "after"; this temporality supposes the existence of a past, a present and a future. However, in contrast, Agamben (2009, 58), notably states that "contemporaneity is a singular relation to time itself, which adheres to it and, at the same time, it takes distances; more precisely, this is the relation with time that it adheres to through $a$ dissociation and an anachronism".

Thereto it is through Friedrich Nietzsche that Agamben $(2009,58)$ turns his gaze to the concept of contemporary and states that "the contemporary is the untimely." It clarifies the Nietzsche's need to understand his own time, demonstrating that in order to conceive the contemporary, it is necessary that the subject is not fit for his own time. In such a way, there is a disconnection, a dissociation, a disagreement with the uses and customs of the period in which it is.

From this angle, it is observed that to reflect on the contemporary is, first of all, to put itself in a situation of break, fracture, disconnection. The contemporary is a state of mind, a condition and is not given as a temporal data, it is an untimely force capable of locating the production of another experience of the subject in relation to time. According to Agamben (2009) he cites the poem "The Century" that Osip Mandelstam wrote in 1923:

My century, my beast, who can look into your eyes and weld with your blood the vertebrae of two centuries? [...] But your back is broken, my stupendous and poor century. With a senseless smile, like a beast a graceful time, you turn back, weak and cruel, to contemplate your footsteps (AGAMBEN, 2009, pp. 60-64, apud MANDELSTAM, 1923). 
Also Agamben $(2009,63)$ states that "the contemporary is the one who keeps the gaze fixed in his time, in order to perceive not the lights but the dark". That said, the author thinks the metaphor of the dark not as the simple absence of light, but something close to non-vision. It means to note that, in this light, to be able to see in obscurity is the condition of being contemporary in its own time. Hence, it is necessary to "neutralize the lights that come from the time to discover its darkness, its darkness, which is not, however, separable from those lights" (AGAMBEN, 2009, p. 63). That is to say, to perceive what is in the "dark" is to silence when the music is exaggeratedly high, is to analyze the social relations amid the chaos, is to seek the sensible through the banal.

However, it is seen that the contemporary, for the Italian philosopher, comes from a crisis, whether social or subjective, experienced in the transition from one time to another. In this path, "an intelligent man can hate his time, but knows, in any case, that it belongs to him irrevocably, he knows that he can not run away without time." (AGAMBEN, 2009, p.59)

Therefore, the present time can only be understood by dissociating itself from it, by turning to the past. For this reason, "contemporaneity is written in the present, pointing out that it is archaic in the first place, and only those who perceive the indices and signatures of the archaic can be contemporary in the most modern and recent" (Agamben, 2009, 69). In other words, the author's analysis corroborates the understanding of present time from the historical construction of the past, where the darkness of now gains answers through the lights of the present projected on the past. For this reason, the contemporary puts into action several temporalities. 
For the study of the contemporary implies, then, to look for the relation with the past, or rather with the archaic, since the arché is not merely chronological, "[...] it is contemporary with the historical becoming and does not cease to operate in this, as the embryo continues to act in the tissues of the mature organism and the child in the psychic life of the adult" (Agamben, 2009, p. 69). Therefore, it seems that there is a particular fascination in the archaic forms about the present, since it is in the past that the key to the modern is found (AGAMBEN, 2009: 70).

This temporality may have a prophetic aspect, that which would come from the past, or a messianic characteristic, that which would come from the future. Thus, this positioning of distinction as well as permanence in the temporal fracture, is close to what Agamben means by revolution. Thus, for the author, the true revolution does not only aim at the economic transformation of the world, but underlines the traces of a change in the experience of the subject over time.

Nothing is more exemplary, in this sense, than the gesture of Paul, at the point where he experiences and announces to his brothers and sisters that contemporaneity par excellence that is the messianic time, the contemporary being of the messiah, which he calls precisely "time-of-now "(ho nyn kairos). Not only is this time chronologically indeterminate (the return of the Christ, the parousia, which marks the end of that time, is certain and close, but incalculable), but he has the singular ability to relate to himself every instant of the past. ... (AGAMBEN, 2009, pp. 71-72)

Walter Benjamin, a German philosopher and sociologist, corroborates Agamben when he states that "the true image of the past passes through us in an elusive way. The past can only be apprehended as an irrecoverable image and suddenly illuminated at the moment of its recognition 
"(BENJAMIN, 2012, p.11). Thus the images of the past exist only in the present moment in which they acquire meaning. It is the present that constantly redefines the past.

In view of this, we seek a new resignification of the relations between time and subjectivity, which is why the contemporary subject is understood as belonging to his time, but he is not content with the unfolding of his time and it is necessary to situate himself from a strategic position to critically understand the direction in which its society, its culture and its history take place in the present time. Finally, Agamben (2009, 65) states that "being contemporary is, above all, a matter of courage."

\subsection{Fashion as a metaphor for the contemporary}

The reflection on the consummate fashion in the contemporary society becomes necessary, because for at least two decades it has undergone transformations and crossed new concepts. This social phenomenon has importance as one of the main fields of study for the understanding of its main characteristics, namely: to be an effective means in the allocation of most of the discourses of contemporaneity. In this perspective, Calanca (2008, pp. 11-12) explains:

By the term "fashion" is meant specifically "the social phenomenon of the cyclical change of customs and habits, choices and tastes, collectively validated and made almost obligatory." In relation to fashion, the term "custom", in the sense of "constant and permanent habit that determines the behavior, behavior, mode of being" of a community, of a social group, refers to the concept of system, structure, that is, a set of several interrelated elements. Taken in isolation, such elements are deprived of value; however, take on meaning at the moment they are linked by a set of rules, collective rules. (CALANCA, 2008, p. 11-12). 
In this way, Lipovetsky (2009, p. 265) argues that the heart of consummate fashion is the present, diverging from the ideology that signals the future, or tradition that points to the past.

In contrast, Agamben $(2009,66)$ states that fashion "introduces in time a peculiar discontinuity, which divides it according to its actuality or inatuity". Thus the 'now' of fashion, the instant that it comes to be, is not identifiable through any stopwatch" (AGAMBEN, 2009, 66). Hence, why the central axis of fashion is in the contemporary and, therefore, changes.

In analyzing the consummate fashion and the contemporary, it is possible to see more clearly that the contemporary one does not cling to the chronology, but it transforms continuously, allowing to understand better the time. Agamben (2009, p. 59) argues that the intelligent and creative human being inserts himself as a contemporary and lives in anachronistic time.

Thus, contemporary projects anachronically in time to maintain or foster a more ambitious dialogue on the present. Consequently, Agamben cites as an example the logic of fashion shows:

[...] the moment of the parade, in which the dress is worn by the only people who are always and only fashionable, the mannequins, who, however, precisely because of this, are never truly in it? Since being fashionable in the "way" or the "way" ultimately will depend on the fact that people of flesh and blood, different from the mannequins - these sacrificial victims of a faceless god - recognize him as such and make her own garment. (AGAMBEN, 2009, p. 67). 
On the catwalk, the timelessness of consummate fashion materializes in clothing and oscillates between the time that has passed and the one whose present has not yet reached or would be to arrive. Therefore, it does not exist to be fashionable, because it is recognized as happening of something that is not yet or that may be someday. "Time of fashion is constitutively advanced to itself, and precisely because of this, also always backward, is always in the form of an unrepeatable threshold between a 'not yet' and a 'no more'" (AGAMBEN, 2009, p. 67)

Moreover, it can be said that "fashion captures the energy of each epoch and transforms into the image, having as support the body", that is, the whole zeitgeist expression of the contemporaneity is converted in an image that consequently portrays as current forms of fashion, such as trends.

Finally, it means that fashion is a metaphor of the contemporary, especially because it is something that, when elaborated, has passed. To say "to be fashionable", therefore, is in itself a contrassense, for fashion is not something static and given; on the contrary, it is in constant mutation, as is time.

\section{FASHION AS A SENSITIVE EXPERIENCE}

From contemporary perspectives the present article also turns its gaze to the experience of the sensitive. Away from the objects that mainly concern the social and political theories, it is sought to point to the sensitive look and its function in the contemporaneity.

Said in such a way, it is intended to observe from the perspective of Emanuele Coccia in his book "The sensible life", as through the experience of the sensitive our senses become more precise and things come to have a meaning. For the author, "the sensitive, the being of images, is not 
something merely psychic: if it were, it would be enough to close our eyes to see and observe anything" (COCCIA, 2010, p.17).

According to Coccia, in order for the sensible to exist "there must be something intermediate [...] It is in this intermediary space that things become sensitive and it is from this same space that the living ones harvest the sensible with which, night and day, nourish their own souls. " (COCCIA, 2010, pp. 19-20).

In this way, it is understood that "the image (the sensible) is nothing other than the existence of something outside the proper place" (COCCIA, 2010, p. 22-24). In front of the mirror the subject becomes something sensitive, an image without body and without consciousness. When a subject stands in front of the mirror, there is a duplication in two separate spheres: the flesh and the spirit; the image and the body, showing that the visibility is even separable from the thing and the subject, and thus, image.

In turn, Coccia (2010, p.23) cites fashion as a representation of the sensitive incarnate. "What, in fact, is dressing rather than incorporating an external sensibility?" From this question, fashion is thought of as an experience of the sensible, and therefore is equivalent in the conception of an image that lies in a place outside itself, in "another place," a locus that is no longer proper, like the image in the mirror. "To be an image means to be outside of oneself, to be alien to one's own body and to one's own soul" (COCCIA, 2010 , 23). Thus, man is the result of the composition of his sensations, of his possibility of being affected by the world: of his sensitive. It is through this sensitive that the world comes to him.

In this sense, fashion will be used as the basic concept of this article. Thus, fashion becomes an experience of the sensitive to the point where the fascination with dress 
is due to the fact that it presents us from the outside. For this reason, "in reality it is always outside of itself that something becomes experienceable: something becomes sensitive only in the intermediate body that is between the object and the subject" (COCCIA, 2010, p.20). It is said:

It is through producing our senses that we produce effects upon reality as living beings (and not as simple objects or natural causes), it is through our appearance (that is, through the sensitive that we emit actively or unconsciously) that we impress upon those around us. In this sense, the relation of the living with the world is neither purely ontological nor merely poetic: that is, it can not be declined neither in the verb to be nor in the verb to do. The living being is not in the world as a stone exists, nor is it limited to having direct relations of action and passion with him: while living, he relates to things through mediality through the sensible that he is able to produce (COCCIA, 2010, p.47).

Fashion is independent and has its own life emancipated from consciousness, it is pure mediation and therefore is the representation of the sensible; human clothing is a cut in the interior of the body, not between the body and its exterior, but between an anatomical body and another prosthetic and purely virtual. Clothing and anatomical body are two realities of the same body "(COCCIA, 2010, p.85). In other words, the body that the garment creates is not conceived by the flesh and nor of any other substance, but of pure appearance.

As a result "man does nothing but acquire and return sensible to the world ... To dream, to draw and even to dress, to make-up or to speak: as we have seen, all these activities are forms of our sensible life which do not coincide, however, with the simple fact of perception "(COCCIA, 2010, $80)$. The sensitive and the image make things exist in 
particular. Experience, the sensible life, is always beyond what it has produced. It is everywhere and in every way.

Similarly, it is seen that fashion presents itself as the experience of the sensitive from the moment it is understood that clothing is a properly human element. "Neither men nor gods have clothes [...] man is an animal that has learned to dress" (COCCIA, 2010, p, 81). That is to say what is aware of itself has fashion.

As a consequence in the impact of the world, in the creation of fashion lies the visible by the features of the hand, presented not only in front of the seams, a pattern or a modeling that fills the place of perceiving, but also in the recognition of the "inner fabric" that clothing may reveal beyond what the eye can see. In fashion, when "we read in the garments their meanings, we use the same faculty of judgment and the same look of those who see a sculpture, painting or architecture" (CELANT, 1999, 176).

Finally, Coccia $(2010,95)$ maintains that "the sensible life is this diffused and impersonal eternity, indifferent to death and birth, the plane in which we can be born and to be reborn continuously, without ever presupposing a past or a history, without having to change ourselves. "We are able to transform our nature into clothes, just because "fashion is the organ of this eternity" and thanks to it we are eternal.

\section{NEON BULL: AN ANALYSIS OF THE CONTEMPORARY AND THE SENSITIVE UNDER THE BIAS OF FASHION}

The present analysis looks at the reflexive intersection of the contemporary, the sensitive and the fashionable through the Brazilian film Neon Bull (2015), by the director from Pernambuco Gabriel Mascaro. 
It is necessary to understanding the identities of the personages of the narrative and of such attributes can be related to the formation of the contemporary people.

In addition, we intend to understand the implications of temporality, sensitive experience and how the phenomenon of fashion is expressed as a metaphor of the contemporary in the film narrative.

Neon Bull escapes from a certain stereotype, notably by drawing the attention of movie critics, once the feature film had its international premiere at the Venice Film Festival, at Orizzonti Mostra, following the Toronto Festival and premiering in Brazil at the Rio Festival. At the Marrakesh Festival, Gabriel Mascaro received several awards, one of them was the best director delivered by the director Francis Ford Coppola, one of the judges of the festival. On account of this, Mascaro, director of the film, says:

Neon Bull sheds light on recent transformations of the country from a narrative clipping that appropriates the lives of a group of cowboys who live on the road carrying oxen to the festivals of Vaquejada, one of the biggest agribusiness events in Brazil. I understand Vaquejada as an allegorical stage of this transformation amidst the monochromatic landscape of the Northeast, I search for the colors that spark the contradictions of consumption and dilate notions of identity and gender in characters that coexist with new scales of possible dreams (BOI NEON, 2015).

In this context, the feature film portrays the daily life and backstage of cowboys in the agreste of the Brazilian Northeast. The film tells the story of Iremar, a character lived by actor Juliano Cazarre, a cowboy who dreams of being a stylist. So, "lying in his hammock in the back of the truck, his head wanders in dreams of sequins, exquisite fabrics and sketches. The cowboy sketches new desires "(BOI NEON, 2015). That is, with the growth of 
industrialization and the textile pole of clothing in the northeastern region, Iremar aims to work in the fashion business, in contracting with his dull and visceral routine. In such a way, "the film is based on a contemporary scenario of economic prosperity governing new signs, drawing new human relationships, affections and desires. It is a film about the transformation of the human landscape. "(BOI NEON, 2015) the feature film portrays the daily life and backstage of cowboys in the agreste of the Brazilian Northeast. The film tells the story of Iremar, a character lived by actor Juliano Cazarre, a cowboy who dreams of being a stylist. So, "lying in his hammock in the back of the truck, his head wanders in dreams of sequins, exquisite fabrics and sketches. The cowboy sketches new desires "(BOI NEON, 2015). With the growth of industrialization and the textile pole of clothing in the northeastern region, Iremar aims to work in the fashion business, in contracting with his dull and visceral routine. In such a way, "the film is based on a contemporary scenario of economic prosperity governing new signs, drawing new human relationships, affections and desires. It is a film about the transformation of the human landscape. "(BOI NEON, 2015)

Consequently, on the road "the truck carrying the oxen to the event is also the improvised house of Iremar and his coworkers: Zé, his corral partner, and Galega - dancer, truck driver and mother of the audacious Caca. Together, they form an improvised and united family "(BOI NEON, 2015).

Also, according to Xavier (2015) "Neon Bull is one of those human experiences that makes us review the way we look at each other." That is to say, through the film, one can shed light on a sensitive eye on individuals trapped inside hostile environments and who, in the face of the darkness of their daily lives, act unconsciously in a contemporary way.

So the film critic Pablo Villaça explains: 
Neon Bull is not a plot film, but a remark: with a narrative conceived from long plans dedicated to accompanying these characters, the film lives up to the documentary origin of the filmmaker by suggesting simply recording events that unfold naturally from the camera - "simplicity". absurdly difficult to reach, clearly depending on a cast steeped in the logic of that world and a direction that must be intimate without sounding intrusive (VILLAÇA, 2015).

The film presents during its unfoldment other characters that go against the paradoxical and hybrid context approached by Mascaro. One such character is Junior (Vinícius de Oliveira), a long-haired cowboy with metrosexual characteristics. In addition to him, one has Geise (Samya de Lavor), a perfume saleswoman, pregnant, who works as a night watchman in a confectionery factory. Therefore, the feature does not violate the secrets of bodies and does not imprison them in an identity that is ready to decode.

Fashion is present throughout the plot as the experience of the sensitive, when the cowboy who has the strength to catch the bulls is the same with delicate hands for the fabric and the seam. That is, for Mascaro, "Neon Bull is a research on bodies, light and transformation of human landscapes," similar to fashion. (BOI NEON, 2015)

In view of this, it is important to note that the title of the film already anticipates some ideas on the themes addressed by Gabriel Mascaro, insofar as the bull refers to the animal, the irrational, the rural, the agrarian, the hostility, the brutality and the omission of an animal manipulated by the human being. In contrast, neon alludes to light, contrast, brightness, illusion, sharpness and visibility. So the title anticipates, even before reaching the narrative, a set of characteristics that provide images, apparently, divergent 
and contrasting, but that are located in proximity in the statement conceived by the director.

Therefore, four scenes of the film were selected by the authors of the present article to be analyzed through the methodology of filmic analysis of image and sound, together with an interpretative study. In this way, the chosen methodology finds strength in the authors Aumont and Marie (2004), who consider the film as "autonomous artistic work, capable of engendering a text that bases its meanings on narrative structures and on visual and sound data, producing an effect in the spectator "(AUMONT; MARIE, 2004, p.10).

Thereby, Aumont and Marie (2004) adopt in their methodology some instruments and techniques to be put into practice, which is the reason why an interpretive image analysis was chosen, under the descriptive bias. For this, some procedures are necessary, such as: plane-to-plane decomposition, to identify the narrative and spatio-temporal units by sequences; segmentation, where delimitation and sequence definitions occur; the description of the image, to transpose in verbal language the elements of information and meaning that the image contains (AUMONT; MARIE, 2004, pp. 46-72).

Even if there is no universal method for analyzing films, the authors point out that it is important to emphasize that if the analysis is meant to be a strict discourse, different from merely interpretive or critical ramblings, it is necessary to have principles and instruments, as mentioned above. Therefore, "all methods must always be specified, and sometimes adjusted, according to the precise purpose they are concerned" (AUMONT; MARIE, 2004, p. For that, the analysis of a film is endless and will never be the same, regardless of the degree of precision and extent that we achieve, in a film always have something analysable, the authors conclude. 
Finally, through the film device used, it is needed to understand the concepts of contemporary and sensitive under the aesthetic experience of fashion in the scenes of the feature film Neon Bull.

\subsection{Scenes analysis}

Neon Bull represents a landmark for the Pernambuco and Brazilian cinema of the 21st century. In this vein, Fan (2015) states that "Gabriel Mascaro created a film of rustic beauty that looks at a very particular microcosm", so that the feature film creates new experiments with the cinematographic language, of notable relevance in the national artistic scene.

In first place the analysis begins with the selection of some scenes that gain prominence during the unfolding of the film and that is the reason why it was tried to prioritize the scenes in which the elements referring to the field of the fashion gained prominence.

Early in the narrative, director Gabriel Mascaro introduces the character Iremar, a cowboy who appears tending the oxen and exercising their function. In this context, the camera strolls between crowded cattle and the character appears combing the tails of the animals, one by one. Then through sounds, cries and whistles he gives the command for the oxen to move forward into the corral. Although the protagonist seems gross and crude to the tanger, in his act of combing the tails of the animals he is strong and careful.

On the other hand, the scenes are interrupted suddenly and Iremar appears in a opened angle, walking in a dump with the floor full of patchwork of colored fabrics and some pieces of mannequins loose on the ground. In this context, the character collects, in the midst of damp earth, the pieces of the dismembered bodies of the mannequins. Such a scenario instigates the spectator to be disturbed by the 
construction of the character. In this way, the image of the protagonist begins to be constructed by the following unfolding

The subsequent scene was chosen to be analyzed as representing the starting point for understanding the protagonist's identity, Iremar.

Figure 1: 00:06:17 Iremar pulling measures from Galega.

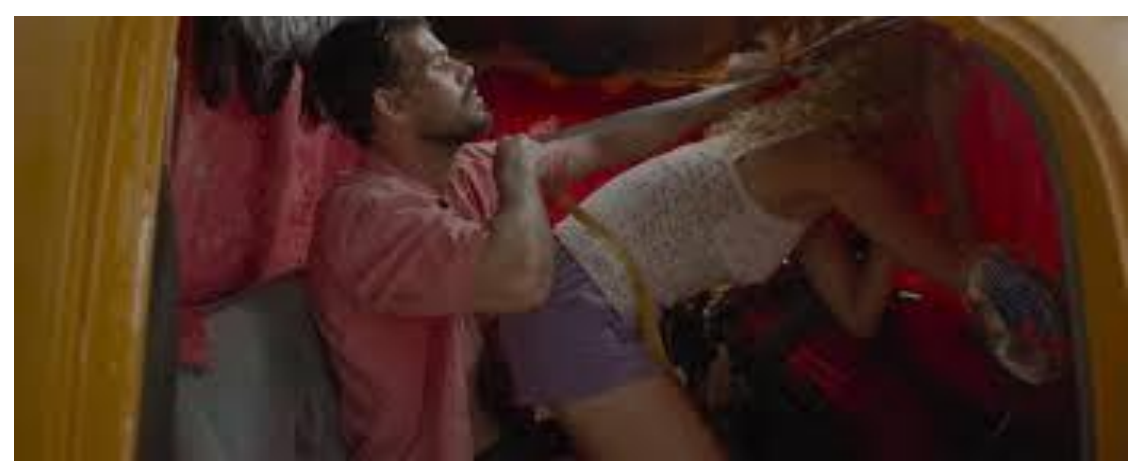

Source: https://www.boineon.com.br/boi-neon-presskit.pdf (2015).

Here the deconstruction of the stereotype is called into question by Mascaro. Inside the cabin of the truck, in a closed plane and medium light, Galega is shown with low shorts serving as a mannequin, while Iremar, dressed in a pink shirt between open, takes his measurements with the aid of a tape measure, an instrument used by fashion professionals for mold making and prototyping. The protagonist is affected to the ludibrious impression on his sexuality, when ignoring carelessly the body of Galega arranged in his front with insinuating poses that allude to sexual positions.

Consequently, the dialogue between the two characters shows that Iremar seems to have information about fashion trends adaptable to that context, for which Galega says: you said that you wanted something strong, I thought of shock pink. Then he replies: - No ... pink shock is girl's 
thing! Then he informs her that he will buy a print of animal print to make the clothes

From there comes a sensitive Iremar, with delicate gestures, putting into practice his construction skills and costume creations for the dancer, in contrast to the rough, virile and strong Iremar of the first scene. In fact, the own traits of the contemporary influencing and installing itself in the construction of the identity of the character.

In addition, fashion is seen as the starting point for the experience of the sensitive, from the moment the protagonist uses elements and methods that make up the creative and experimental field of fashion. Then Cellant argues that the act of producing and creating is "that experience which comes not from mere intellectual and external judgment, but from direct perception. [...] Such sensitivity also directs his doing and his work "(CELLANT, 1999, p.170). It means to say Iremar breaks with stereotypes of the Brazilian Northeast, as well as with the speeches made around the masculinity, since the character plays a hybrid performance that moves between cowboy and the stylist, human and animal, male and female, breaking paradigms sociocultural and giving rise to new possibilities of being.

Moreover, the second scene chosen for analysis shows the body sitting in a swing netting drawing, unpretentiously, under the body of models of a pornographic magazine. Nudity does not seem to disrupt the protagonist; on the contrary, Iremar is professionally familiar with the bodies exposed in the sketch to recover the woman's sexuality, showing herself interested in the female body as shaping her own fashion creations. Those inventions show that he is trying to be a good designer, not only because of a social ascension, but caused by a deep identification with the profession. 
Figure 2: 00:22:02 Iremar draws on pornographic magazine.


Source: https://www.boineon.com.br/boi-neon-presskit.pdf

(2015).

Therefore, in the midst of this hostile environment, Iremar appears to be sensitive and out of standards. Well, therefore, it is seen that the sensible is not born through the cognitive processes, it exists, rather, outside any psychic field. That is why, according to Coccia (2010, p.19) "for there to be something sensible, there must be something intermediate." Thus, it is understood that the sensibility is to understand what goes on "between" the material bodies of the objects and the human bodies that they feel and think. That is, before the drawing, the pen and the magazine there is something intermediate that transpasses the character, the experience of the sensitive.

Then Coccia (2010, p 14) concludes that "every man lives in the midst of sensitive experience and can only survive through sensations", which is why what Iremar sees is perceived through sensations, which lie between him and the world. This world, as a sensible life, is constituted by its habits and its participation in the most diverse fields; but from and beyond that, there is between him and things the sensation, through which the character appropriates the sensitive. It is she who strengthens the feeling that does not leave you passive before what you look at.

In view of this, in the third moment of the analysis it was opted for a sequence of scenes that represent the conflict lived by the protagonist Iremar: 
Figure $3-00: 45: 46$ Sequence showing the contrast of the character's daily life.
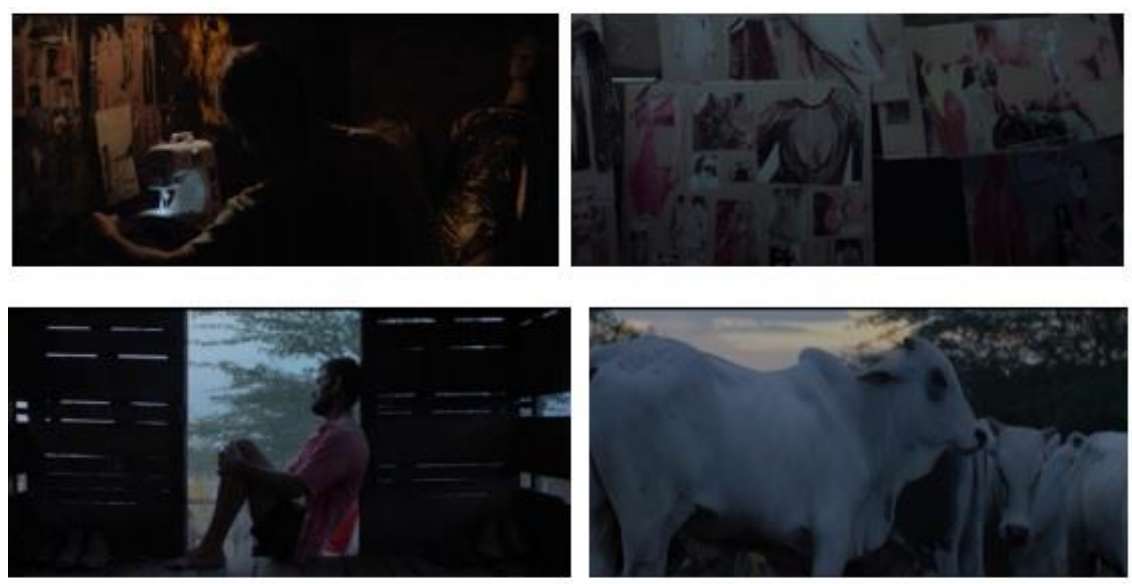

Source: Frame Neon Bull (2015).

In this case, in the silence and darkness of the night, Iremar appears seated in front of a sewing machine (figure 3), while his friends amuse themselves outside. Thus, the protagonist seems, in a way, to escape the reality that is inserted. According to Agamben (2010: 59) "contemporaneity, therefore, is a singular relation with time itself, which adheres to it and, at the same time, takes it from distances", reason why the author adds that " those who coincide very fully with the age, who in all respects perfectly adhere to it, are not contemporaries "(AGAMBEN, 2010, 59).

In this way, attentive and sensitive, Iremar seems to be submerged and caught up in the act of creation, where the idealized piece begins to take form and life through sewing. As such, the camera invades in your personal space and you can observe under the inner walls of your truck, clippings from fashion magazines with pictures of sexy modeling dresses, deep necklines, scintillating fabrics under the bodies of women, showing your preference by the segment of women's clothing. In addition, in the form of a visual briefing, the reference panel used by creative professionals, Iremar, within its limitations, develops its research of 
inspirations and tendencies for the making of the model in development. Thus, the experience of the sensitive is made in the narrative of the present scene, corroborating with Kant's $(1983,39)$, when he exclaims that "every intuition is sensible." That is, sensitivity is a faculty of intuition, through which objects are apprehended by the knowing subject.

So the scene is interrupted by Iremar sitting on the door of the truck at dawn of day, hands under his knee, looking at the seemingly reflective local landscape. In this contrasting environment between dream and reality, the internal conflict of the character becomes exposed. Thus, when observing the cattle, the protagonist projects itself to the dream of a different life. This dichotomy translates the discrepancies of the present and the idealization, corroborating the tenor of Nietzsche's untimely considerations, "which wants to settle the accounts with their time, to take a position in relation to the present" (AGAMBEN, 2010, 58). , that "being contemporary means, in this sense, to return to a present in which we have never been", especially because:

It is in this sense that one can say that the way of access to the present necessarily has the form of an archeology that does not, however, regress to a remote past, but to everything that in the present we can never live and, lived, is unceasingly re-launched into the origin, without ever being able to attain it. Since the present is nothing but the part of unlived in all lived, and that which prevents access to the present is precisely the mass of that which, for some reason (its traumatic character, its extreme proximity), in this we can not live (AGAMBEN, 2010, p.70).

In another twist, in an antagonistic way, the sequence of scenes is highlighted by Mascaro, through folds that oscillate between the character at his creative and sensitive moment and his rough cowboy side. This contradiction emphasizes in Neon Bull an indefinable narrative construction that wanders 
between the fluid constructions of its personages. In this sense, Iremar represents the figure of the contemporary, who visualizes in the dark a possibility of exodus and seeks progress in the present in which he finds himself. Well for this reason, "the contemporary is the one who perceives the dark of his time as something that concerns him and never ceases to question him, something that, more than all light, directly and singularly directs himself to him [...] ] is the one who receives in full the face of darkness that comes from his time "(AGAMBEN, 2010, 64).

Finally, it is necessary to analyze also the scene interpreted by Galega in his performance with the costume developed by Iremar.

Figure 4: 00:07:39 Galega performance with costumes created by Iremar.

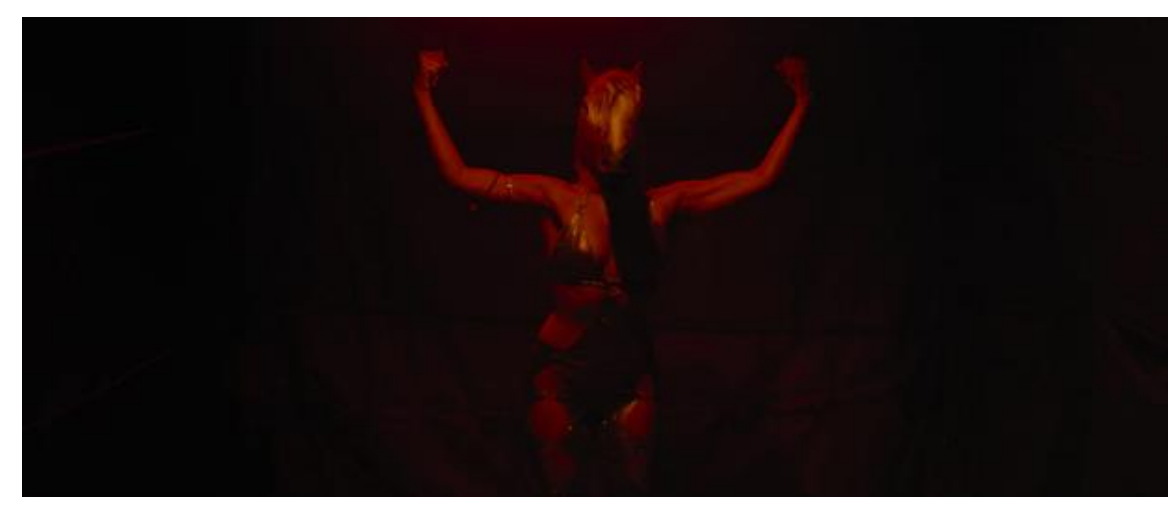

Source: Frame Neon Bull (2015).

In this case the fashion is materialized in the costume of Galega, a woman truck driver and dancer, who appears under the stage with low lights staging exotic movements while the audience shouts in ecstasy. In this context, Iremar puts on the scene his creation, a front-only coverall made of golden lame fabric, which allows to observe in the details of the clothing the presence of the research of tendencies made by the protagonist through the cuts of women's fashion magazines.

However, Agamben explain: 
[...] the "now" of fashion, the instant that it comes to be, is not identifiable through no stopwatch. Is this "now" perhaps the moment when the stylist conceives the trait, the nuance that will define the new way of dress? Or the one in which he entrusts it to the designer and then to the tailor making the prototype? Or the moment of the parade, where the dress is worn by the only people who are always and only in fashion, the mannequins, who, however, precisely because of this, are never truly in it? Since being fashionable in the "way" or the "way" ultimately will depend on the fact that people of flesh and blood, different from the mannequins - these sacrificial victims of a faceless god - recognize him as such and make her own garment.

In addition, the costume of the dancer is composed of a horse-head mask, which stands out strangely in the presentation of Galega, who moves with slow, sexual and animalistic gestures. Thus, it transits between the various signs that carries in its body, in an environment in which the women would be destined to the stereotype of mother, of the home or of wife, Galega becomes contemporary and it breaks the standards. Hence clothes become a disquieting device, automaton and mannequin, statue and machine, dream and nightmare figure, delirious and scenographic simulation, so that the costume "becomes a vector of a fantastic and fascinating impulse that reactive to the dreamed logic of clothing as play and pleasure, life and spectacle, mask and travestiment (CELLANT, 1999, p.176).

Therefore, through the scenes analyzed above, one can observe the stages of the process of creation and development of a garment and how fashion indicates one of the ways of experiencing the sensitive in its purest essence. The narrative of the feature film takes us to a contemporary world of sensations, between the present and the past, the new and the old, a fusion in which it does not refer to a rupture or to a bond whose time is interpolated and it 
reconfigures itself as an inter-place, producing complex figures of difference and identity, inner and outer, inclusion and exclusion. Thus, as Agamben asserts, being contemporary is transforming and placing time in relations with other times and in it uncritically reading, quoting and writing history (AGAMBEN, 2010, 72).

\section{CONCLUSIONS}

Through the film analysis it is possible to observe the transformations that involve human relations in general, operating as a reflection of an environment that, in rapid development, preserves and breaks its traditions and consequently the contradictions. Therefore, the characters of Neon Bull point to the contemporary subject who escapes traditional identity models, reinventing a new culture and observing time.

It was understood that the neon - as well as the contemporary - is the one that shines in the dark of his century, in the words of Agamben. Carrying this thought to the case under analysis, it is seen that Iremar, cowboy rough and virile, represents the contemporary who gives himself up to becoming sensitive through the experience of creating clothes. In this sense, seeing under the lenses of contemporaneity enabled the character to construct a way of read his time and the environment in which he is located, in order to dreaming of the exodus of being a stylist, the protagonist shifted and became a "Foreign-natural", who was born an ox, but wants to be neon.

However it has been observed that in the work there are empty informations that create gaps to be filled and that evoke an incomplete and unanswered future about the characters' path. In this way, identity and time coexist and oscillate with each other, corroborating with what Agamben (2010, p. 65) says, "the present that contemporaneousness 
perceives has its broken vertebrae $[\ldots]$, for time, the present, not can in no case reach us. His back is fractured and we hold ourselves exactly at the point of fracture. That is why we are, after all, contemporaries at this time".

Thereupon, Neon Bull dialogues not only with the local context of the rural man, but with other cultures that deal with the processes of formation of identities and human relations, addressing current issues such as the deconstruction of gender stereotypes, the hybridism, the binarism between human and nature and the breaking of cultural paradigms.

\section{REFERENCES}

AGAMBEN, Giorgio. O que é o contemporâneo e outros ensaios. São Paulo: Argos, 2009.

AUMONT, Jacques e MARIE, Michel. A análise do filme. Lisboa: Texto e Grafia, 2004.

Boi Neon. Direção de Gabriel Mascaro. Produzido por: Desvia, Malbicho Cine e Viking Films. Imovision, 2015.

Boi Neon. Desvia Filmes, Cine e Viking Films. Imovision, 2015. Disponível em: <https://www.boineon.com.br> Acesso em: 06 nov. 2018.

BRITO, João Batista de. Imagens amadas. São Paulo: Ateliê editorial, 1995.

CALANCA, Daniela. História social da moda. São Paulo: Senac, 2008.

CELANT, Germano. Cortar é pensar: arte \& moda In: PRADILHA, Céron; REIS, Paulo. Kant: crítica e estética na modernidade. São Paulo: Editora Senac SP, 1999

COCCIA, Emanuele. A vida sensível. Tradução: Diego Cervelin. -. Florianópolis: Cultura e Barbárie, 2010.

GABRIEL MASCARO. Gabriel Mascaro. Disponível em: <http://pt.gabrielmascaro.com/>. Acesso em: 10 nov. 2018.

HOLZMEISTER, S. O estranho na moda. São Paulo:

Estação das Letras e Cores, 2010. 
KANT, Immanuel. Crítica da razão pura. Trad. Valerio Rohden e Udo Baldur Moosburger. São Paulo: Abril cultural, 1983

LIPOVETSKY, Gilles. O Império do Efêmero: A moda e seu destino nas sociedades modernas. São Paulo: Companhia das Letras, 2009.

SCHOPENHAUER, Arthur. O mundo como vontade e como representação. São Paulo: UNESP, 2005.

VILLAÇA, Pablo. Crítica - Boi Neon. Cinema em cena, São Paulo, 2015. Disponível em: <http://cinemaemcena.cartacapital.com.br/Critica/Filme/82 06/boi-neon> Acesso em: 04 de nov. 2018.

WALTER, Benjamin. O anjo da história. Trad. João Barreto. Editora Autêntica, São Paulo. 2012.

XAVIER, Ingrid. Boi neon duas perspectivas sobre o filme. Cinegrafando, São Paulo. 2015. Disponível em: <http://cinegrafando.com/2015/11/08/boi-neon-duasperspectivas-sobre-o-filme/> Acesso em: 06 de nov. 2018. 